\title{
Concurrent studies of the flow of digesta in the duodenum and of exocrine pancreatic secretion of calves
}

\section{4.* The effect of age}

\author{
By J. H. TERNOUTH†, J. H. B. ROY AND SUSAN M. SHOTTON \\ National Institute for Research in Dairying, \\ Shinfield, Reading $R G 2{ }_{9} A T$
}

(Received I March 1976-Accepted 8 April 1976)

\begin{abstract}
I. The effect of age on the flow of duodenal digesta and of pancreatic secretion was studied in preruminant calves fitted with duodenal re-entrant and pancreatic sac cannulas. In Expt I a comparison was made at 7,24 and $63 \mathrm{~d}$ of age of Ayrshire calves given whole milk, and in Expt 2 Friesian calves given milk-substitute diets were studied during the period 16-37 d of age.

2. For the Ayrshire calves, $a d l i b$. whole-milk intake increased with age, but whole-milk intake on a per $\mathrm{kg}$ metabolic body-weight $\left(\mathrm{W}^{0.75}\right)$ basis did not alter. As the intake increased with age, the whey fluids were passed out of the abomasum more rapidly.

3. As judged by the mean duodenal $\mathrm{pH}$ values and the values for 'chloride ion minus sodium ion' concentration in the digesta, and for apparent secretions (total quantity recovered at duodenal cannula during $12 \mathrm{~h}$ after feeding minus intake) the duodenal digesta became more acid as the Ayrshire calves became older. There was no change with age in the extent of degradation of the milk proteins as indicated by the protein-nitrogen: total $\mathrm{N}$ values for duodenal digesta.

4. The volume of pancreatic fluids secreted by the Ayrshire calves increased markedly with age, but when expressed on a per $\mathrm{kg} \mathrm{W}^{0.75}$ the volume did not increase after $24 \mathrm{~d}$ of age. In absolute terms and also in relation to whole-milk intake or $W^{0.75}$ there was a large increase in secretion of total protease, a very large increase in $\alpha$-amylase ( $E C C_{3.2}$. I . I) but no change in trypsin ( $E C 3.4 .4 .4)$ activities with age.

5. In the Friesian calves secretion of pancreatic fluid and activities of $\alpha$-chymotrypsin ( $E C$ $3.4 .4 .5), \alpha$-amylase, lipase $\left(E C C_{3} .1 .1 .3\right)$ and ribonuclease $(E C 2.7 .7 .16,2.7 .7 .17)$ but not trypsin or total protease increased with age.

6. The extent of the increase in secretion of pancreatic enzymes during the first hour after the Friesian calves were fed milk-substitute diets differed between enzymes.

7. The changes in the quantities of pancreatic enzymes secreted are discussed in relation to the changes in the digestibility of milk-substitute diets.
\end{abstract}

The neonatal ruminant is considered to be immature in terms of its ability to secrete acid and pepsin ( $E C$ 3.4.23.1) from the abomasal mucosa (Hill, Noakes \& Lowe, 1970) but the effect of this immaturity upon the digestive efficiency of the abomasum does not appear to have been studied. Knowledge of the changes with age in the quantities of enzymes secreted by the pancreas of the calf is also limited (Zerebcov \& Seryh, 1962; Morrill, Stewart, McCormick \& Fryer, 1970).

In the calf, it has been found that the greater the quantity of milk fed, the longer is the time required for all the whey fluids to leave the abomasum (Ternouth, Roy \& Siddons, 1974). Only when most of the whey fluids have left the abomasum is the secretion of acid able to lower the $\mathrm{pH}$ of the abomasal fluids so that rapid digestion of the casein clot can occur (Mylrea, I966a, $b$; Ternouth, Roy \& Siddons,

* Paper no. 3: Br. F. Nutr. (1975), 33, r8r.

$\uparrow$ Present address: Department of Animal Husbandry, Faculty of Veterinary Science, University of Queensland, St Lucia, Queensland 4067, Australia. 
I974). With the increase in voluntary milk intake of calves as they grow, it appears necessary for the rate of abomasal emptying to change to accommodate this increased intake.

To study these effects of age, six Ayrshire calves used in an earlier experiment (Ternouth, Roy \& Siddons, I974) were given whole milk, and the results compared in Expt $I$ at a mean age of 7,24 and $63 \mathrm{~d}$. A re-analysis of results obtained from Friesian calves (Ternouth, Roy, Thompson, Toothill, Gillies \& Edwards-Webb, 1975), to study the effects of age in this breed, is reported in Expt 2. A preliminary communication of some of these results has been published (Ternouth, Siddons $\&$ Toothill, r97 I).

\section{EXPERIMENTAL}

Expt I. Six Ayrshire calves with duodenal re-entrant and pancreatic sac cannulas (Ternouth \& Buttle, I973) were offered whole milk at $39^{\circ}$ ad lib. by teat twice daily at 09.00 and 21.00 hours. The calves were given at least three feeds of whole milk before the beginning of the collection periods, which were between 6 and 8,22 and 27 and 55 and $75 \mathrm{~d}$ of age. Polyethylene glycol (PEG) (approximately $\mathrm{I} g / \mathrm{l}$ ) was added to the milk fed at the beginning of the collection period. The methods used for collecting, sampling and returning the duodenal digesta and the pancreatic secretions have been described previously (Ternouth, Roy \& Siddons, 1974). The age of the calves, their live weight and the quantity of milk consumed at each experimental meal are given in Table $\mathrm{r}$. Calves nos. I and 2 were slaughtered before they reached $50 \mathrm{~d}$ of age. The results for three collections (calf no. I $25 \mathrm{~d}$, calf no. 36 and 24 d) have been omitted because of abnormally low milk intakes. Before the analysis of the pancreatic samples could be completed, the final samples of calves nos. 5 and 6 (73-75 and 66-68 d respectively) were inadvertently lost.

The technique of Bartlett (1934) for dealing with missing values was used in the analysis of variance statistical programme.

Expt 2. The effect of age has been obtained from a re-analysis of the results of an experiment presented in a previous paper (Ternouth et al. 1975). That experiment was a comparison made during the period from 16 to $37 \mathrm{~d}$ of age of four milksubstitute diets given by teat to four Friesian calves cannulated as in Expt I. Each diet was given for twelve consecutive meals, the experimental collections being made after the 6th and 12th meals. To minimize loss of enzyme activity, particularly of $\alpha$-amylase $(E C$ 3.2.I.I), lipase $(E C$ 3.I.I.3) and ribonuclease $(E C$ 2.7.7.16, 2.7.7.17), during the collection, the pancreatic fluids were collected in a stainlesssteel container surrounded by a jacket of ice. All other experimental conditions were similar to those described in Expt I.

\section{Analyses}

The chemical and enzyme assay techniques have been described by Ternouth, Roy \& Siddons (1974) and Ternouth et al. (1975). 
Table I. Expt I. Live weight and whole-milk intake of six Ayrshire calves at various ages from 6 to $75 d$ old

\begin{tabular}{|c|c|c|c|c|c|}
\hline \multirow{2}{*}{$\begin{array}{l}\text { Calf } \\
\text { no. }\end{array}$} & \multirow{2}{*}{$\begin{array}{c}\text { Live } \\
\text { weight } \\
\text { (kg) }\end{array}$} & \multicolumn{4}{|c|}{ Whole-milk intake } \\
\hline & & Age (d) & Intake (1) & Age (d) & Intake (1) \\
\hline I & $\begin{array}{l}36 \cdot 0^{*} \\
41 \cdot 0\end{array}$ & $\frac{6}{-t}$ & $\begin{array}{r}2.80 \\
--1\end{array}$ & $\begin{array}{r}8 \\
27\end{array}$ & $\begin{array}{l}3 \cdot 64 \\
4.94\end{array}$ \\
\hline 2 & $\begin{array}{l}36 \cdot 0^{*} \\
42 \cdot 0\end{array}$ & $\begin{array}{r}6 \\
24\end{array}$ & $\begin{array}{l}3 \cdot 27 \\
2 \cdot 20\end{array}$ & $\begin{array}{r}8 \\
26\end{array}$ & $\begin{array}{l}3.79 \\
3.55\end{array}$ \\
\hline 3 & $\begin{array}{l}34 \cdot 0 * \\
38 \cdot 0 \\
51 \cdot 0\end{array}$ & $\begin{array}{l}-\dagger \\
22 \\
55\end{array}$ & $\begin{array}{c}-\uparrow \\
3 \cdot 18 \\
5.23\end{array}$ & $\frac{8}{57}+$ & $\begin{array}{r}2 \cdot 93 \\
\frac{1}{4 \cdot 64}\end{array}$ \\
\hline 4 & $\begin{array}{l}44 \cdot 0 * \\
51 \cdot 0 \\
67 \cdot 0\end{array}$ & $\begin{array}{r}6 \\
22 \\
55\end{array}$ & $\begin{array}{l}2 \cdot 91 \\
5.09 \\
3 \cdot 73\end{array}$ & $\begin{array}{r}8 \\
24 \\
57\end{array}$ & $\begin{array}{l}3.55 \\
5 \cdot 27 \\
4.68\end{array}$ \\
\hline 5 & $\begin{array}{l}37 \cdot 0^{*} \\
48 \cdot 0 \\
68 \cdot 0\end{array}$ & $\begin{array}{r}6 \\
22 \\
73\end{array}$ & $\begin{array}{l}3.41 \\
5.00 \\
4.30\end{array}$ & $\begin{array}{r}8 \\
24 \\
75\end{array}$ & $\begin{array}{l}4.05 \\
3.41 \\
5.07\end{array}$ \\
\hline 6 & $\begin{array}{l}34 \cdot 0^{*} \\
42 \cdot 0 \\
59 \cdot 0\end{array}$ & $\begin{array}{r}6 \\
22 \\
66\end{array}$ & $\begin{array}{l}3 \cdot 61 \\
5.07 \\
5.73\end{array}$ & $\begin{array}{r}8 \\
24 \\
68\end{array}$ & $\begin{array}{l}3.84 \\
3.87 \\
6.07\end{array}$ \\
\hline
\end{tabular}

* Birth weight.

+ Values for calf no. $I$ at $25 \mathrm{~d}$, and for calf no. 2 at 6 and $24 \mathrm{~d}$ were omitted because of abnormally low intakes.

Table 2. Expt 1. Mean whole-milk intakes and duodenal digesta flow-rates of Ayrshire calves at three ages

\begin{tabular}{|c|c|c|c|c|c|c|c|}
\hline & \multicolumn{3}{|c|}{ Mean age (d) } & \multirow{2}{*}{$\begin{array}{l}\mathrm{SE} \text { of } \\
\text { mean }\end{array}$} & \multicolumn{3}{|c|}{$\begin{array}{c}\text { Statistical significance of } \\
\text { differences between } \\
\text { ages }\end{array}$} \\
\hline & 7 & 24 & 63 & & 7 v. 24 & 24 v. 63 & $7 v .63$ \\
\hline No. of calves & 6 & 6 & 4 & & & & \\
\hline Whole-milk intake (1) & $3 \cdot 53$ & $4 \cdot 16$ & $4 \cdot 69$ & 0.23 & - & 一 & $* *$ \\
\hline \multicolumn{8}{|c|}{$\begin{array}{l}\text { Duodenal digesta flow }(\mathrm{ml}) \text { in the } \\
\text { following periods }(\mathrm{h}) \text { after feeding: }\end{array}$} \\
\hline $\begin{array}{l}0-3 \\
3-6 \\
6-9 \\
9-12\end{array}$ & $\begin{array}{r}2039 \\
1811 \\
1040 \\
766\end{array}$ & $\begin{array}{r}2626 \\
1662 \\
1081 \\
847\end{array}$ & $\begin{array}{l}3136 \\
2015 \\
1214 \\
1009\end{array}$ & $\begin{array}{l}256 \\
214 \\
105 \\
109\end{array}$ & $\begin{array}{l}- \\
-\end{array}$ & $\frac{-}{-}$ & * \\
\hline $\begin{array}{l}\text { Total flow-rate: } \\
\mathrm{ml} / \mathrm{I} 2 \mathrm{~h} \\
\mathrm{ml} / \mathrm{l} \text { whole-milk intake } \\
\mathrm{ml} / \mathrm{kg} \mathrm{W} \mathrm{W}^{0.75}\end{array}$ & $\begin{array}{r}5655 \\
1608 \\
386\end{array}$ & $\begin{array}{r}6218 \\
1536 \\
366\end{array}$ & $\begin{array}{r}7374 \\
\mathrm{r} 593 \\
335\end{array}$ & $\begin{array}{r}273 \\
62 \\
15\end{array}$ & - & - & $\begin{array}{l}* * * \\
- \\
-\end{array}$ \\
\hline
\end{tabular}

\section{RESULTS}

Expt I. The intake of whole milk increased with age (Table 2), the mean live weights were $36 \cdot 8,43 \cdot 7$ and $6 \mathrm{r} \cdot 3 \mathrm{~kg}$ at 7,24 and $63 \mathrm{~d}$ and the daily whole-milk intakes were equivalent to 56,60 and $56 \mathrm{~g}$ dry matter (DM) $/ \mathrm{kg}$ metabolic body-weight $\left(\mathrm{W}^{0.75}\right)$ respectively for whole milk containing $125 \mathrm{~g} \mathrm{DM} / \mathrm{kg}$. These intakes determined 
Table 3. Expt I. Mean duodenal $p H$, and concentrations and total outflows of hydrogen, sodium, potassium and chloride ions during $12 h$ after feeding whole-milk for Ayrshire calves at three ages

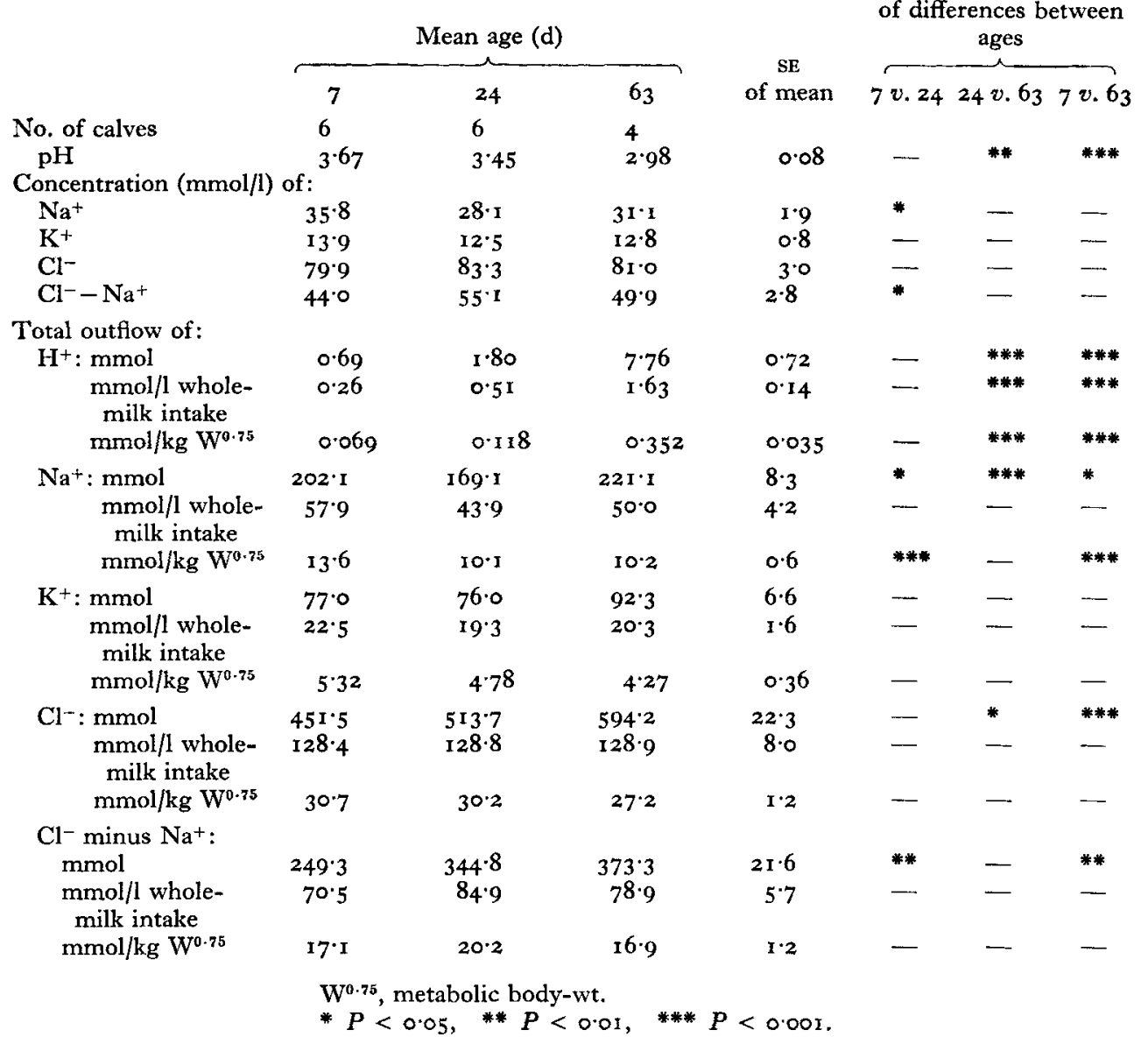

for calves sucking teats are similar to the maximal daily intakes recorded by Roy (1970) for bucket-fed Friesian calves given reconstituted milks containing $138 \mathrm{~g} \mathrm{DM} / \mathrm{kg}$. The pattern of flow of duodenal digesta which was shown in Fig. 3 of Ternouth \& Buttle (I973) is indicated in results given in Table 2. At the older ages more duodenal digesta were collected and returned to the calf, reflecting the increased whole-milk intake and also the increased volume of apparent secretion at $63 \mathrm{~d}$ (Table 4). The increased volume of duodenal digesta at older ages was found throughout the i $2 \mathrm{~h}$ postprandial period, although it was more marked during the first $3 \mathrm{~h}$ after feeding. When the rate of PEG outflow was expressed on a square-root basis (Ternouth, Roy \& Siddons, 1974), the mean period of time after feeding (h) for all PEG to leave the abomasum was unaffected by age, the values being $9.5,9.7$ and $9 \cdot 0$ (SE \pm 0.85 ) at 7,24 and $63 \mathrm{~d}$ of age respectively. 
Table 4. Expt I. Mean apparent secretion $\dagger$ of fluid and 'chloride ions minus sodium ions' in the duodenal digesta during $12 h$ after feeding whole-milk for Ayrshire calves at three ages

\begin{tabular}{|c|c|c|c|c|c|c|c|}
\hline & & lean age & & & of diffe & $\begin{array}{l}\text { erences be } \\
\text { ages }\end{array}$ & etween \\
\hline & 7 & 24 & 63 & of mean & $7 v .24$ & $24 v .63$ & $7 v .63$ \\
\hline No. of calves & 6 & 6 & 4 & & & & \\
\hline $\begin{array}{l}\text { Volume of fluid: } \\
1 \\
1 / 1 \text { whole-milk intake } \\
1 / \mathrm{kg} \mathrm{W}^{0.75}\end{array}$ & $\begin{array}{l}2.13 \\
0.61 \\
0.145\end{array}$ & $\begin{array}{l}2.06 \\
0.54 \\
0.123\end{array}$ & $\begin{array}{l}2.69 \\
0.59 \\
0.121\end{array}$ & $\begin{array}{l}0.16 \\
0.06 \\
0.009\end{array}$ & - & $\begin{array}{l}* \\
-\end{array}$ & - \\
\hline $\begin{array}{l}\text { ' } \mathrm{Cl}^{-} \text {minus } \mathrm{Na}^{+} \text {': } \\
\text { mmol }\end{array}$ & 1994 & $287 \cdot I$ & $307 \cdot 2$ & $20 \cdot \mathrm{I}$ & $* *$ & - & ** \\
\hline $\begin{array}{l}\text { mmol/1 whole-milk } \\
\text { intake }\end{array}$ & $56 \cdot 2$ & $71 \cdot 0$ & $64 \cdot 8$ & $5 \cdot 6$ & - & - & - \\
\hline $\mathrm{mmol} / \mathrm{kg} \mathrm{W}^{0.25}$ & 13.7 & $16 \cdot 8$ & 13.9 & $\mathbf{r} \cdot \mathrm{I}$ & - & - & - \\
\hline $\mathrm{mmol} / \mathrm{l}$ fluid secreted & 947 & $143^{\circ} \mathrm{I}$ & I I $9 \cdot 3$ & $18 \cdot 1$ & $*$ & - & - \\
\hline
\end{tabular}

The mean $\mathrm{pH}$ and the total outflow of hydrogen ions in the $\mathrm{I} 2 \mathrm{~h}$ period after feeding changed significantly with age, the duodenal digesta becoming more acid in the older calves (Table 3 ). The general pattern of flow during the $\mathrm{i} 2 \mathrm{~h}$ collection period was similar to that described by Ternouth, Roy \& Siddons (1974). During the first $4 \mathrm{~h}$ after feeding, no consistent differences with age were found in the $\mathrm{pH}$ of the duodenal digesta, but after $4 \mathrm{~h}$, the duodenal $\mathrm{pH}$ values were lower as the calves became older.

The total outflow of sodium, chloride ions, and ' $\mathrm{Cl}$ - minus $\mathrm{Na}^{+}$' increased at the older ages, but this increase could be accounted for by the increased wholemilk intake or by the increased $W^{0.75}$ of the calves (Table 3 ). At the earliest age studied, the concentration of $\mathrm{Na}^{+}$was significantly higher than at older ages but the concentration of $\mathrm{Cl}^{-}$did not change with age. These changes are reflected in the ' $\mathrm{Cl}^{-}$minus $\mathrm{Na}^{+}$' concentration which increased significantly between 7 and $24 \mathrm{~d}$ of age. The total quantity of apparent secretion (total quantity recovered at duodenal cannula during $\mathrm{I} 2 \mathrm{~h}$ after feeding minus intake) of ' $\mathrm{Cl}-$ minus $\mathrm{Na}^{+}$' and its concentration also increased significantly between 7 and $24 \mathrm{~d}$ of age, but the total quantity did not differ with age when related to whole-milk intake or $W^{0 \cdot 75}$ (Table 4).

The pattern of nitrogen, protein and fat outflow in the duodenal digesta during the $12 \mathrm{~h}$ collection period is shown in Fig. $\mathrm{I}$. As there was no significant difference in the pattern between ages, a single mean value is shown. As a result of the coagulation of the casein, the concentrations of $N$, protein and fat were lower $2-4 \mathrm{~h}$ after feeding (Ternouth, I97I), and especially in the instance of fat considerably higher 6-Io h after feeding. The difference in outflow of $\mathrm{N}$, protein and fat with age could be largely accounted for by differences in whole-milk intake. The extent 


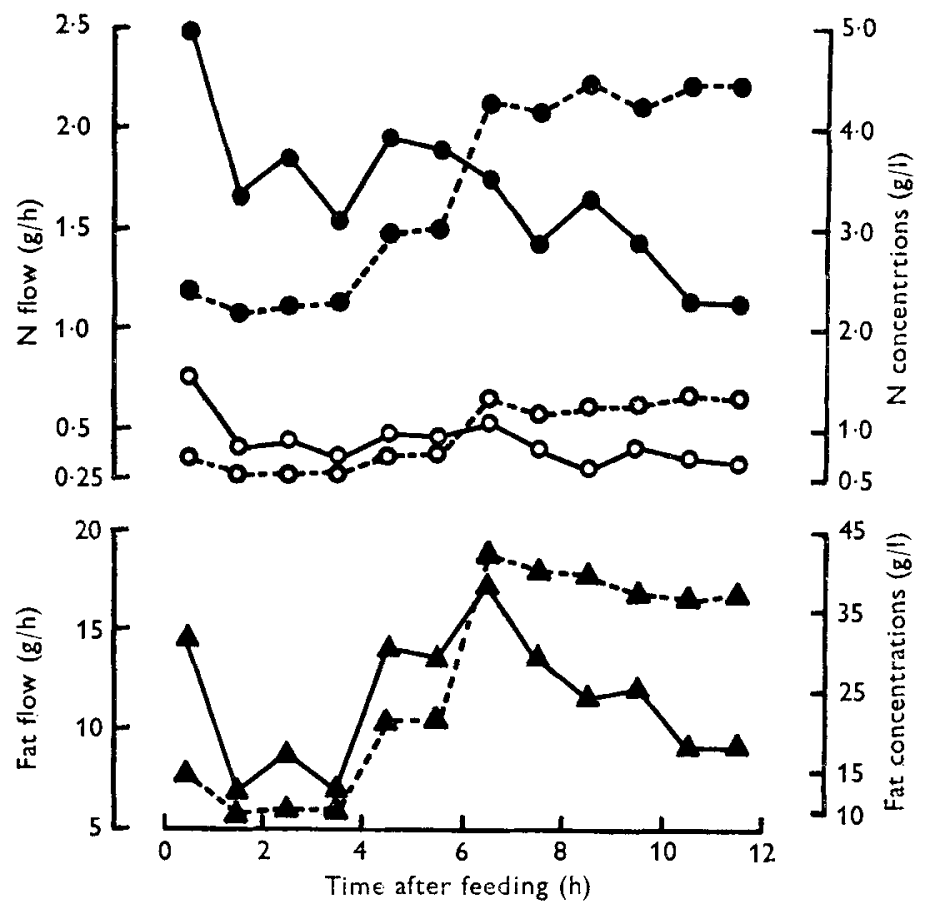

Fig. I. Expt I. Mean hourly total flow $(\mathrm{g} / \mathrm{h})(-)$ and concentration $(\mathrm{g} / \mathrm{l})(--.-)$ of nitrogen $(\bullet)$, protein-N $(\mathrm{O})$ and fat $(\Lambda)$ through the duodenum of Ayrshire calves during $\mathrm{I} 2 \mathrm{~h}$ after feeding whole milk.

of degradation of the protein, as indicated by the value for protein- $\mathrm{N}$ : total $\mathrm{N}$, did not change with age (Table 5).

The changes in the volume of pancreatic secretion with age were large (Table 6). The pattern of secretion over a $12 \mathrm{~h}$ period (Ternouth \& Buttle, I973), indicated that calves had higher secretion rates as they became older, although the differences were small in the period $2-4 \mathrm{~h}$ after feeding, when the rate of secretion was lower than at any other time in the $12 \mathrm{~h}$ postprandial period. The volume of pancreatic secretion on a per 1 whole-milk intake basis increased with age, but no increase was apparent when secretion rate on a per $\mathrm{kg} \mathrm{W}^{0.75}$ basis was considered.

Total trypsin ( $E C 3 \cdot 4 \cdot 4 \cdot 4)$ activity tended to increase with age (Table 7 ), although the non-significant change was almost entirely due to changes in the volume of pancreatic secretion rather than to a change in trypsin activity on a per $\mathrm{ml}$ pancreatic secretion basis. There was nearly a fourfold increase in the total protease activity between 7 and $24 \mathrm{~d}$ of age and a further twofold increase between 24 and $63 \mathrm{~d}$. Changes in the $\alpha$-amylase activity were so marked that the results were transformed into a logarithmic scale before being analysed statistically.

Expt 2. Changes in the pancreatic secretion of the four Friesian calves, given four milk-substitute diets between the ages of 16 and $37 \mathrm{~d}$ of age, are indicated by results given in Table 8 . The regressions were calculated after removing the variability associated with differences between diets and between calves. With the exception 
Table 5. Expt 1 . Mean duodenal outflow of protein, nitrogen and fat during $12 h$ after feeding whole milk for Ayrshire calves at three ages

Statistical significance of differences between

\begin{tabular}{|c|c|c|c|c|c|c|c|}
\hline & \multicolumn{3}{|c|}{ Mean age (d) } & \multirow{2}{*}{$\begin{array}{c}\mathrm{SE} \\
\text { of mean }\end{array}$} & \multicolumn{3}{|c|}{ ages } \\
\hline & 7 & 24 & 63 & & 7 v. 24 & $24 v .63$ & 70.63 \\
\hline No. of calves & 6 & 6 & 4 & & & & \\
\hline \multicolumn{8}{|l|}{ Total N: } \\
\hline $\mathrm{g}$ & 16.84 & $20 \cdot 59$ & $21 \cdot 50$ & $1 \cdot 06$ & $\bullet$ & $\longrightarrow$ & $* *$ \\
\hline $\mathrm{g} / \mathrm{l}$ whole-milk intake & $4 \cdot 72$ & $5 \cdot 12$ & $4 \cdot 76$ & 0.35 & - & - & - \\
\hline $\mathrm{g} / \mathrm{kg} W^{0.75}$ & $I \cdot I 5$ & $1 \cdot 20$ & 0.97 & 0.06 & 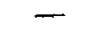 & - & $\longrightarrow$ \\
\hline \multicolumn{8}{|l|}{ Protein-N : } \\
\hline $\mathrm{g}$ & $3 \cdot 92$ & $5 \cdot 55$ & $6 \cdot 6 I$ & 0.54 & - & - & ** \\
\hline $\mathrm{g} / \mathrm{l}$ whole-milk intake & $\mathrm{I} \cdot \mathrm{I} 4$ & $1 \cdot 36$ & $1 \cdot 46$ & 0.12 & - & - & - \\
\hline $\mathrm{g} / \mathrm{kg} \mathrm{W} \mathrm{W}^{0.75}$ & 0.27 & 0.33 & 0.30 & 0.03 & - & - & - \\
\hline Protein-N: total $\mathrm{N}$ & 0.240 & 0.266 & 0.313 & 0.021 & - & - & - \\
\hline \multicolumn{8}{|l|}{ Fat: } \\
\hline $\mathrm{g}$ & $119 \cdot 6$ & $141 \cdot I$ & $143 \cdot 6$ & $12 \cdot 3$ & 一 & - & $\longrightarrow$ \\
\hline $\begin{array}{l}\mathrm{g} / 1 \text { whole-milk intake } \\
\mathrm{g} / \mathrm{kg} \mathrm{W} \mathrm{W}^{0.75}\end{array}$ & $\begin{array}{l}34 \cdot 0 \\
8 \cdot 22\end{array}$ & $\begin{array}{l}36 \cdot 2 \\
8 \cdot 32\end{array}$ & $\begin{array}{l}31 \cdot 0 \\
6 \cdot 30\end{array}$ & $\begin{array}{l}4.0 \\
0.66\end{array}$ & - & - & - \\
\hline
\end{tabular}

Table 6. Expt $\mathrm{x}$. Volume of pancreatic secretion after feeding whole milk for Ayrshire calves at three ages

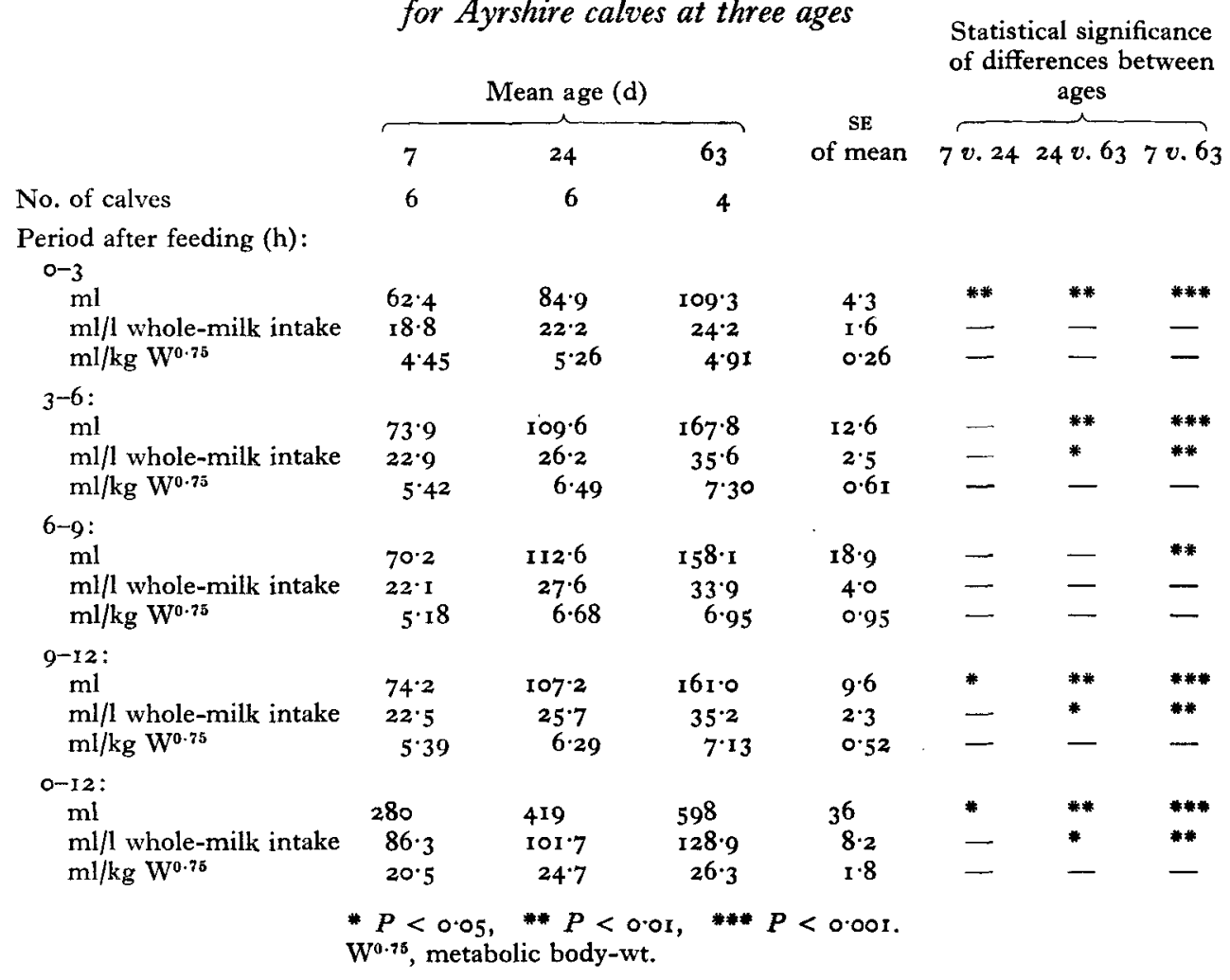


Table 7. Expt 1. Mean secretion of enzymes $(m g / 12 h)$ by the pancreas during $12 h$ after feeding whole-milk for Ayrshire calves at three ages

\begin{tabular}{|c|c|c|c|c|c|c|c|}
\hline & \multicolumn{3}{|c|}{ Mean age (d) } & \multirow{2}{*}{$\begin{array}{c}S E \\
\text { of mean }\end{array}$} & \multicolumn{3}{|c|}{$\begin{array}{c}\text { Statistical significance } \\
\text { of differences between } \\
\text { ages }\end{array}$} \\
\hline & 7 & 24 & 63 & & $7 v .24$ & $24 v .63$ & 7 v. $6_{3}$ \\
\hline No. of calves & 6 & 6 & 4 & & & & \\
\hline $\begin{array}{l}\text { Trypsin }(E C 3 \cdot 4 \cdot 4 \cdot 4) \text { : } \\
\text { mg } \\
\text { mg/l whole-milk intake } \\
\mathrm{mg} / \mathrm{kg} \mathrm{W} W^{0.75}\end{array}$ & $\begin{array}{l}\text { I33.1 } \\
39^{\circ} \circ \\
9^{\circ} 54\end{array}$ & $\begin{array}{c}169 \cdot 9 \\
36 \cdot 7 \\
9 \cdot 73\end{array}$ & $\begin{array}{r}191 \cdot 6 \\
49 \cdot 6 \\
8 \cdot 74\end{array}$ & $\begin{array}{l}47 \cdot 1 \\
9 \cdot 6 \\
2 \cdot 72\end{array}$ & - & - & - \\
\hline $\begin{array}{l}\text { Total Proteases: } \\
\text { mg } \\
\text { mg/l whole-milk intake } \\
\text { mg/kg W }{ }^{0.75} \\
\alpha \text {-Amylase }(E C \text { 3.2. I . I })\end{array}$ & $\begin{array}{r}399 \\
164 \\
5 I \cdot 0 \\
8 \cdot 9\end{array}$ & $\begin{array}{l}2701 \\
580 \\
162 \cdot 8 \\
46 \cdot 8\end{array}$ & $\begin{array}{l}5065 \\
1248 \\
227 \cdot 1 \\
269 \cdot 2\end{array}$ & $\begin{array}{l}785 \\
150 \\
39 \cdot 8 \\
\text { na }\end{array}$ & - & $\begin{array}{l}\bar{*} \\
\overline{* *}\end{array}$ & $\begin{array}{l}* * \\
* * * \\
* \\
* * *\end{array}$ \\
\hline
\end{tabular}

$\mathrm{W}^{0.35}$, metabolic body-wt; na, sE not available as values transformed for analysis. * $P<0.05$, ** $P<0.01, * * * P<0.001$.

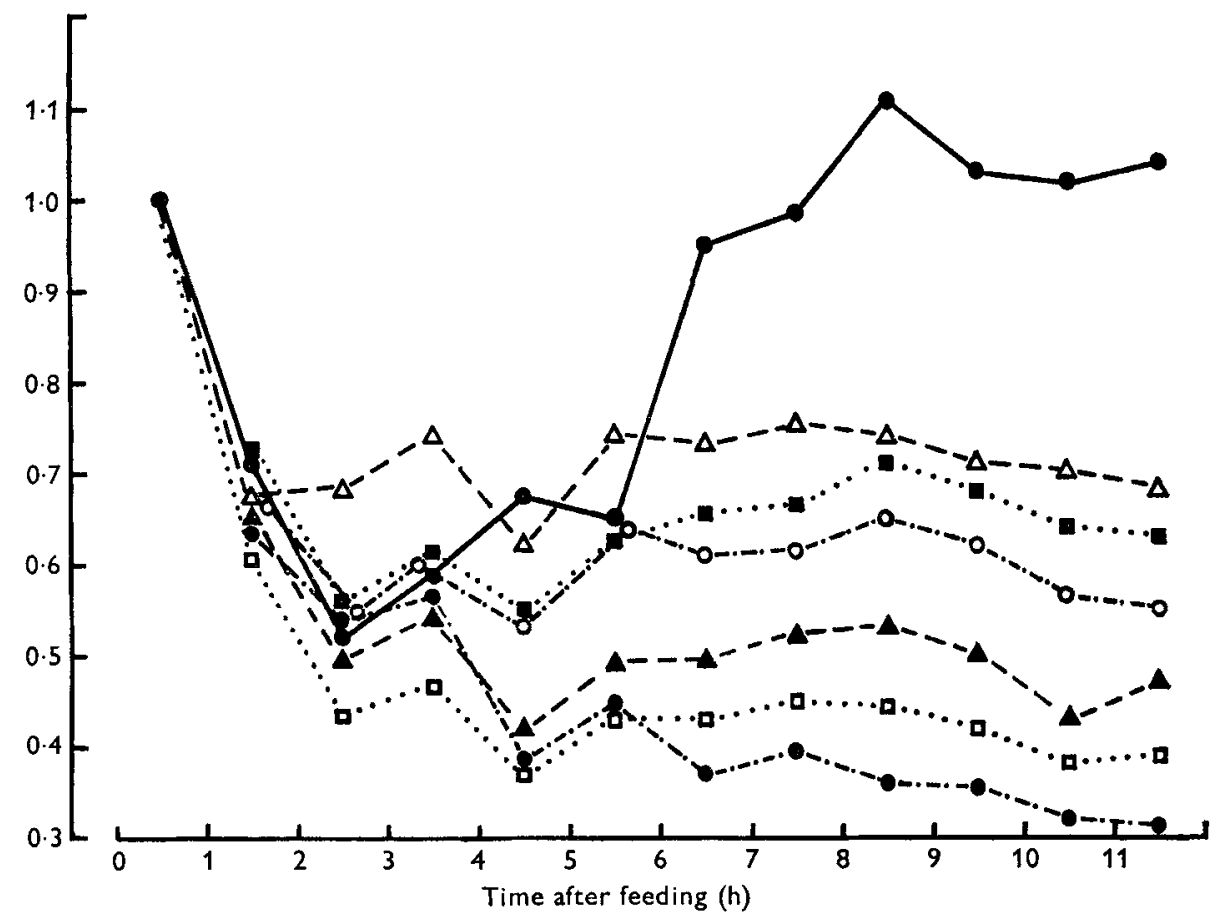

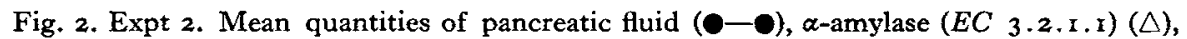
ribonuclease $(E C$ 2.7.7.16,2.7.7.17) (⿴), $\alpha$-chymotrypsin ( $E C$ 3.4.4.5) (O), trypsin $(E C 3.4 .4 .5)(\Lambda)$, lipase $\left(E C C_{3}, 1.1 .3\right)(\square)$ and total protease (0) activities secreted by four Friesian calves during $12 \mathrm{~h}$ after feeding relative to those secreted during the first hour after feeding milk-substitute diets (for details of diets, see Ternouth, Roy, Thompson, Toothill, Gillies \& Edwards-Webb (1975)). 


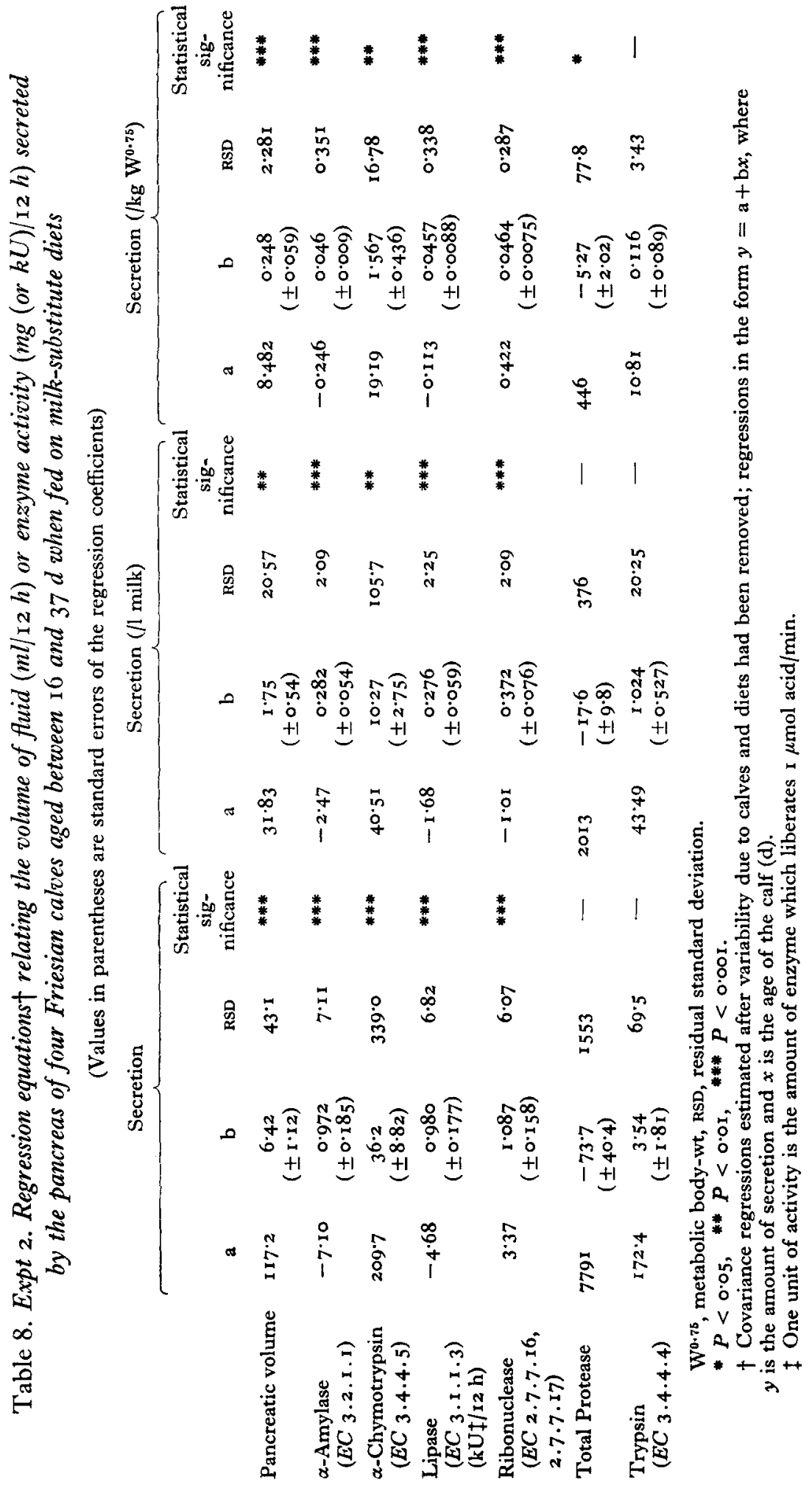


of the total proteases, which tended to decrease with age, the total activities of all the other pancreatic enzymes and the pancreatic volume increased with age, except that the increase for trypsin was not significant. The mean daily rate of increase in secretion of pancreatic fluids was $+2 \cdot 26 \%$. The corresponding values for $\alpha$ amylase, $\alpha$-chymotrypsin $(E C 3.4 \cdot 4 \cdot 5)$, lipase and ribonuclease were $+5 \cdot 36,+4.94$, +4.72 and $+3.45 \%$ respectively. For the non-significant regressions for trypsin and total proteases, the values were $+\mathrm{r} \cdot 34$ and $-\mathbf{r} \cdot 25 \%$ respectively. Although the calves were allowed to suck their diets ad lib. at each meal, there was no significant change in the intake of milk-substitute with age over the experimental period (Ternouth et al. 1975) so that the regressions of pancreatic secretion expressed per $\mathrm{kg}$ whole-milk intake and per $\mathrm{kg} \mathrm{W}^{0 \cdot 75}$ were similar.

Fig. 2 shows the mean quantities of pancreatic fluid and enzyme activities secreted by Friesian calves during $\mathrm{I} 2 \mathrm{~h}$ after feeding relative to those secreted during the first hour after feeding. The quantities of each enzyme remained constant between 3 and $12 \mathrm{~h}$ after feeding, whilst the volume of pancreatic fluid increased to a level greater than $\mathrm{I} \cdot \mathrm{O}$ between 6 and $\mathrm{I} 2 \mathrm{~h}$ after feeding.

\section{DISCUSSION}

The changes associated with age found in these experiments could have been confounded by residual effects of the surgical procedure, but as no abnormalities of gastrointestinal function, e.g. diarrhoea, were noted at any time and all the calves were consuming relatively large quantities of milk within $3 \mathrm{~d}$ of the surgical operation, these residual effects were considered to be small.

It was evident from the results of Expt $\mathrm{I}$ that the calf adapted to increased wholemilk intake with increasing age so that additional time was not required for the abomasal emptying of larger quantities of whole milk. Ternouth, Roy \& Siddons (1974) found that as the quantity of whole milk was increased at a given age, the period of time required for all of the PEG to pass out of the abomasum is also increased. In the present experiment, the additional quantities of whole milk consumed by the older calves passed out of the abomasum within similar periods of time. The mean values for complete PEG outflow (h) of $9.5,9.7$ and 9.0 for the three ages may be compared with values of $8.8,9.6$ and 10.8 respectively, obtained by applying the regression equation, OT $=6 \cdot 2+0 \cdot 864 \mathrm{MI}$ (Ternouth, Roy \& Siddons, 1974), where OT is the mean period of time for PEG outflow (h), and MI is the mean whole-milk intake (l) of the calves at the three ages. The faster rate of abomasal emptying in the older calves is associated with a relatively greater weight of abomasal and intestinal tissue due to increases in both gut length and the thickness of the gut wall (Warner, Flatt \& Loosli, 1956; Wardrop \& Coombe, 1960; Large, I964; Siddons, 1968).

Ternouth, Roy \& Siddons (1974) used the ' $\mathrm{Cl}^{-}$minus $\mathrm{Na}^{+}$' concentration as a second indicator of the quantity of abomasal acid secretion. However, Sasaki (1968) found a considerable increase in the concentration of bicarbonate ions and a decrease in the concentration of $\mathrm{Cl}^{-}$in the saliva of the older preruminant calf, and this may preclude the use of the ' $\mathrm{Cl}^{-}$minus $\mathrm{Na}^{+}$' values in the duodenal effluent 
of the 63 -d-old calf. Between 7 and $24 \mathrm{~d}$ of age, there was a significant increase in the ' $\mathrm{Cl}^{-}$minus $\mathrm{Na}^{+}$' concentration and a significant reduction in the mean $\mathrm{pH}$ although there was an increased buffering capacity resulting from increased protein intake. Between 24 and $63 \mathrm{~d}$ of age, a further reduction in $\mathrm{pH}$ occurred. It is thus evident that at least for the first 4 weeks of life, the abomasal secretion of acid increases. Hill (1956) has reported changes in the numbers of parietal cells present in the abomasal mucosa of the neonatal lamb but comparable values do not appear to be available for the calf. The outflow of almost $75 \%$ of the total $\mathrm{N}$ as nitrogenous material soluble in dilute trichloroacetic acid solution $(20 \mathrm{~g} / 1)$ at all three ages suggests that the quantities of abomasal enzymes and acid secreted are adequate, even at a young age, to maximize the abomasal proteolysis of whole milk.

The absolute volume of pancreatic secretion and the volume in relation to milk intake was found to increase with age, both between 7 and $63 \mathrm{~d}$ of age in Ayrshire calves and between 16 and $37 \mathrm{~d}$ of age in Friesian calves; these results are in keeping with those obtained by Gorrill, Thomas, Stewart \& Morrill (1967) and McCormick \& Stewart (1967). However, on a $W^{0.75}$ basis there was no increase in secretion with age in Ayrshire calves. The pattern of secretion within a $12 \mathrm{~h}$ period (see Fig. 3 of Ternouth \& Buttle (1973)) suggests that the increase in secretion is due to greatly increased glandular response to some form of stimulation.

Reynolds (1972) found that intravenous infusion of secretin in adult sheep, caused an immediate fourfold increase in the volume of pancreatic secretion but no change in the quantities of trypsin, $\alpha$-chymotrypsin and $\alpha$-amylase secreted apart from a temporary initial increase (a wash-out effect). In the period 6-12 h after feeding in our experiments, the increased secretion of pancreatic fluid but not enzymes (Fig. 2) is due to stimulation by secretin. If the constant levels of enzyme secretion between 3 and $\mathrm{I} 2 \mathrm{~h}$ after feeding are considered to be 'basal' for the calf in a postprandial state, then the only stimulus to increased secretion during the whole $12 \mathrm{~h}$ post-prandial period was the act of feeding. During the first hour after feeding, the level of secretion was $39,5 \mathrm{I}, 66, \mathrm{I} 04, \mathrm{I}^{8} 8$ and $185 \%$ higher than the 'basal' rate for $\alpha$-amylase, ribonuclease, $\alpha$-chymotrypsin, trypsin, lipase and total protease activities respectively. In the adult sheep, non-parallel secretion of enzymes as a result of vagal stimulation has been found by Reynolds (1972). He found a I-5-fold increase in the flow of pancreatic fluid and a $3-5$-fold increase in trypsin, $\alpha$-chymotrypsin and $\alpha$-amylase concentrations. The very high rates of secretion of certain enzymes may indicate their importance in the preruminant calf (total protease, lipase and trypsin). $\alpha$-Chymotrypsin may be of less importance because it hydrolyses the same peptide bonds as pepsin and rennin $(E C 3.4 .23 .4)$. In contrast to the high values for single-stomached animals, the value for $\alpha$-chymotrypsin:trypsin in ruminant animals generally is close to $\mathrm{I} \cdot \mathrm{O}$, while the value for preruminants is 0.39-0.54 (Gorrill \& Thomas, 1967; Gorrill et al. 1967; Schingoethe, Gorrill, Thomas \& Yang, 1970). The higher value for this ratio in the older, weaned calf may be associated with the more uniform pancreatic secretion in the ruminanting animal (Taylor, 1962; J. H. Ternouth, J. H. B. Roy, I. J. F. Stobo, S. M. Shotton \& C. M. Gillies, unpublished results). 
When fats are re-incorporated into skim milk, the digestibility is considerably increased by homogenization and the use of emulsifying agents (Hopkins, Warner \& Loosli, r959; Roy, Shillam, Thompson \& Dawson, r96r; Thomke, I963a; Raven \& Robinson, I964; Toullec \& Mathieu, I969; Raven, I970). Although there is no indication that there is insufficient lipase in the young calf fed whole milk, lipase activity may be limiting when the quantity of substrate available to be hydrolysed is reduced by blending fats with skim milk, i.e. by a direct reduction in the interfacial area, or indirectly by a shortage of emulsifying agent to remove the hydrolysed fatty acids from the interfacial area. Under these conditions the increased digestibility of fat with increasing age (Thomke, $1963 b$; Raven \& Robinson, 1964) accords with the increased secretion of lipase found in the present experiment.

Although comparisons between the two experiments need to be treated with caution, Friesian calves appeared to secrete considerably more total protease (g activity/ I2 h) (6.0 cf. 2.8) but less $\alpha$-amylase (mg activity/I2 h) (16.0 cf. 57.5) than Ayrshire calves at a mean age of $24 \mathrm{~d}$. As the diets fed to the two breeds of calves differed both before and during the experiments, it cannot be concluded that these are true breed differences. However, it could be more than mere coincidence that Friesian in comparison with Ayrshire calves have higher digestibilities of milk-protein at the same age, are less susceptible to diarrhoea when fed on skim milk and have higher faecal DM contents (Roy, I970; Roy, Stobo \& Gaston, 1970; Ternouth, Roy, Stobo, Ganderton, Gillies \& Shotton, 1974). Shillam \& Roy (1963) and Roy, Stobo, Gaston, Shotton \& Ganderton (1973) have also reported lower apparent digestibilities of $\mathrm{N}$ in $\mathrm{I}$-week-old Ayrshire calves than in older calves.

The authors wish to thank Dr J. Toothill, Mr E. Florence and Miss C. M. Gillies for undertaking some of the chemical analyses and enzyme assays. J.H.T. wishes to thank the Australian Dairy Produce Board for their financial assistance.

\section{REFEREN CES}

Bartlett, M. S. (1934). $\mathscr{J l} R$. statist. Soc. Suppl., r, 252.

Gorrill, A. D. L. \& Thomas, J. W. (1967). Ұ. Nutr. 92, 215.

Gorrill, A. D. L., Thomas, J. W., Stewart, J. E. \& Morrill, J. L. (1967). Y. Nutr. 92, 86.

Hill, K. J. (1956). Q. Fl exp. Physiol. 41, 421.

Hill, K. J., Noakes, D. E. \& Lowe, R. A. (1970). In Physiology of Digestion and Metabolism in the Ruminant, p. 166 [A. T. Phillipson, editor]. Newcastle upon Tyne: Oriel Press.

Hoplkins, D. T., Warner, R. G. \& Loosli, J. K. (1959). F. Dairy Sci. 42, 1815.

Large, R. V. (1964). Anim. Prod. 6, 169.

McCormick, R. J. \& Stewart, W. E. (1967). Y. Dairy Sci. 50, 568.

Morrill, J. L., Stewart, W. E., McCormick, R. J. \& Fryer, H. C. (1970). F. Dairy Sci. 53, 72.

Mylrea, P. J. (1966a). Res. vet. Sci. 7, 333.

Mylrea, P. J. (r966b). Res. vet. Sci. 7, 394.

Raven, A. M (1970). \%. Sci. Fd Agric. 21, 352.

Raven, A. M. \& Robinson, K. L. (1964). F. Soc. Dairy Technol. 17, 5.

Reynolds, J.D. (1972). Transport and secretion of pancreatic enzymes in the sheep. BSc (Hons) Thesis, University of New South Wales, Australia.

Roy, J. H. B. (1970). The Calf, vol. 2, 3rd ed. London: Butterworths.

Roy, J. H. B., Shillam, K. W. G., Thompson, S. Y. \& Dawson, D. A. (196r). Br. F. Nutr. 15, 541.

Roy, J. H. B., Stobo, I. J. F. \& Gaston, H. J. (1970). Br. F. Nutr. 24, 459.

Roy, J. H. B., Stobo, I. J. F., Gaston, H. J., Shotton, S. M. \& Ganderton, P. J., (r973) Anim. Prod. I7, 109.

Sasaki, Y. (1968), Yap. F. zootech. Sci. 39, 333. 
Schingoethe, D. J., Gorrill, A. D. L., Thomas, J. W. \& Yang, M. G. (1970). Can. F. Physiol. Pharmac. 48, 43 .

Shillam, K. W. G. \& Roy, J. H. B. (1963). Br. F. Nutr. 17, I71.

Siddons, R. C. (1968). Biochem. \%. ro8, 839 .

Taylor, R. B. (1962). Res. vet. Sci. 3,63.

Ternouth, J. H. (197I). Studies of the role of the abomasum and pancreas in digestion in the young calf. PhD Thesis, University of Reading.

Ternouth, J. H. \& Buttle, H. L. (1973). Br. F. Nutr. 29, 387.

Ternouth, J. H., Roy, J. H. B. \& Siddons, R. C. (I974). Br. F. Nutr. 3I, I3.

Ternouth, J. H., Roy, J. H. B., Stobo, I. J. F., Ganderton, P. J., Gillies, C. M. \& Shotton, S. M. (1974). Br. F. Nutr. 32, 37.

Ternouth, J. H., Roy, J. H. B., Thompson, S. Y., Toothill, J., Gillies, C. M. \& Edwards-Webb, J. D. (1975). Br. F. Nutr. 33, 181.

Ternouth, J. H., Siddons, R. C. \& Toothill, J. (I97I). Proc. Nutr. Soc. 3r, 89A.

Thomke, S. (1963a). Züchtungskunde 35, 215.

Thomke, S. ( $1963 b)$. Züchtungskunde 35, 265.

Toullec, R. \& Mathieu, C. M. (1969). Annls Biol. anim. Biochim. Biophys. 9, 139.

Wardrop, I. D. \& Coombe, J. B. (1960). F. agric. Sci., Camb. 54, I40.

Warner, R. G., Flatt, W. P. \& Loosli, J. K. (1956). F. agric. Fd Chem. 4, 788.

Zerebcov, P. I. \& Seryh, M. M. (1962). Izv. timiryazev. sel'.-khoz. Akad. no. 4, p. 214. 